\title{
Profit and Economic Growth
}

\author{
Gennady Bilych \\ Dept. of Management, UPEC Corporation, Belgorod \\ 20 Popova str., 308000, Belgorod, Russia \\ Tel: 7-472-220-2033Ｅ-mail: genatdht@ yandex.ru
}

Received: August 23, 2012 Accepted: September 25, 2012

doi:10.5296/ber.v2i2.2285 URL: http://dx.doi.org/10.5296/ber.v2i2.2285

\begin{abstract}
Many facts attest to the existence of close ties between producer profits and economic growth. In the first place, in periods of economic growth, an overwhelming number of enterprises have fairly high profits. The markets are dominated by general confidence and optimism. A wholly different picture can be seen when economic growth is absent. In crisis conditions, producer profits tend towards zero, a few enterprises have insignificant profits and others suffer losses. In the second place, profits serve as the main source of investments, and as such the magnitude of economic growth depends on the amount of profit. If loans are a source of investment, then the guarantee for its repayment is precisely profit. The amount of loans received is directly dependent on the size of profits. In the third place, in a simple, commodity exchange economy the sole potential for generating profits is acquisition of additional commodities. It follows that the total profit of all economic agents is precisely equal to the cost of additionally manufactured commodities. As such, total profit equals economic growth. In such an economy, the words "profit" and "economic growth" practically become synonyms. If it can be proven that the stated equality always occurs, in any economy, then it will become possible to explain in a fairly simple manner the cyclical nature of economic development, to understand the reason for the existence of interest, and to continue drawing together the two branches of economic science: micro- and macroeconomics.
\end{abstract}

Keywords: Economic growth, Profit, Perfect competition, Imperfect competition, Economic cycles, Economic crisis, Rent, Interest

\section{Several Problems of Modern Economic Theory and their Potential Solutions}

Perfect competition markets continue to arouse unrelenting interest on the part of professional economists, despite the fact that they are highly specific, the outer limit of more realistic models of imperfect competition markets. In no time or place have all of the many conditions for existence of such markets taken shape in a real economy; there are but a few sectors of the economy in particular countries that distantly resemble perfect competition markets. 
However, such interest is understandable and easily explained. In the first place, only in conditions of perfect competition can available resources be effectively distributed, which enables the maximum production of goods and services, which in turn is the primary task of any economic policy. In the second place, imperfect competition is always connected with one or another form of monopoly, which has always given rise to resentment and disapproval among economists. Imperfect competition markets are not in a condition to effectively distribute resources. Production is on a lower level than is possible with the given level of scientific and technological development. There is an obvious need for outside intervention in market mechanisms, which will make it possible to make the market more perfect than it was. As a result, production will become more effective and the population will receive more goods and services. (Mas-Colell, 1982; Debreu, 1959). This is why the study of perfect competition markets has always been and will always be an extremely important task for the science of economics.

All this is well known and would not need to be recalled if not for one problem. This problem is well known to the economist, who has long persistently attempted to solve it. The problem consists of the fact that in conditions of perfect competition producer profits and economic growth inevitably trend towards zero. Resources generate compensation equal to their marginal product and there is nothing from which to take a profit. (For example, Stigler, 1957). Because of this, enterprises do not have means for investment. This results in the fact that, in creating a perfect competition market, we kill economic growth. There was a compelling need to refute such paradoxical conclusions. It is unsurprising that there followed attempts to conceive of profit as compensation for a specific factor of production like "entrepreneurial talent," or to include it in wages for the owner of the means of production. But this doesn't solve the problem since there are significant differences between factors of production and entrepreneurs or owners. Factors of production generate compensation at the beginning of the production process but entrepreneurs or owners generate compensation after the sale of a final product. Having distributed all assets at the beginning of the production process, entrepreneurs and owners may not generate any sort of compensation after the sale of products. In order to conclusively dispel doubt on this topic, we'll turn our attention to one more fact that, strangely enough, remained unnoticed by everyone. In a closed economic system, the wages of all workers must, at any moment in time, be equal to the total cost of consumer goods and services that are produced. If wages are less than the cost of manufactured products, then not all commodities will be purchased. If wages exceed the cost of products, then it can be assumed that the enterprise is taking losses. Their expenses exceed their gains. The following question arises: where did the owners of these enterprises acquire the additional funds and why do they expend them in such a strange way? But, even in this case, equality is inevitably conserved: commodities will appreciate or negligent owners will reduce the compensation for their workers. And so, for a closed economy, we have the equation:

$$
p Q=w L_{s}
$$


where $p$ is the cost of a final product, $Q$ is the quantity of products, $w$ is wages and $L$ is the quantity of workers. In conditions of perfect competition, when resources are used with maximum effectiveness, economic growth is impossible. If there was any sort of way to use some resource more effectively, then this would mean that the market is not in a state of perfect competition. For an enterprise that has managed to utilize such a possibility, the marginal product of a resource would exceed its cost. For such an enterprise, competition is not perfect. It has the potential to pay slightly more for a resource than others and in this way receive profits and expand production. Other producers will rush to copy its technology, and after a short time production will achieve the highest possible level and profits will disappear. From this moment forward, growth in production ceases and the market becomes a perfect competition market. It follows that the absence of growth is the defining trait of perfect competition. Under these conditions an economy reaches the limit of its productive potential. Any attempt to reduce expenses and generate profit will lead to a reduction in overall gains. Profit for a particular enterprise is possible only at the expense of losses to another: a zero sum game. There are no savings or investment in such conditions and earnings suffice only to purchase the commodities produced. It should be noted here, that such a state of affairs, surprisingly, calls to mind an economic crisis. Economic growth is absent, there is no profit, and there is no way to pay interest for loans received earlier. Attempts to decrease expenditures through personnel reductions lead to a decrease in overall production and deflation, as shown by equation (1). For an individual enterprise, output can be represented as follows:

$$
p q=w l+r k
$$

where $q$ is the quantity of products produced by the enterprise, $l$ is the number of workers at

the enterprise, $r$ is the cost of capital and $k$ is the quantity of capital. The second summand, on the right of the equation, $(r k)$ is the wages of workers occupied in the area of production of capital goods, because it is only in this case that equation (1) will hold true. We inevitably come to the conclusion that the labor theory of value is valid, in any case, for perfect competition markets. It is also valid in conditions of imperfect competition, as will be shown below. Things are slightly more complicated because profits, savings, investment and economic growth come into the picture. But goods sense suggests that equation (1) should hold true. But where, here, is the exploitation that to this day troubles some heads? It does not exist and cannot exist. If owners underpay their workers and leave these funds for themselves, nothing whatsoever will change for the workers. They will buy up the entire product that is produced. Producers will be required to reduce their prices if they want to sell all their commodities. Real wages will remain unchangeable. The money withheld by owners of the means of production can be utilized for the purchase of capital, but in this way they will increase wages or increase activity in the sector for production of capital goods. As before, money will be located in the hands of the hired workers. And, in the end, the owners of 
enterprises can direct the funds taken from the workers towards the acquisition of consumer goods. Such a means of using additional funds is sufficient for maintaining gains at the previous level, but it should be recognized as extravagant. Enterprise owners purchase produced commodities either from one another or from themselves in order to maintain the previous level of sales. This method is devoid of purpose because before all else enterprise owners require capital and not bread and cucumbers.

There is one more surprising conclusion that follows from equation (1). If a single enterprise has a total monopoly in a closed economy, then in the absence of economic growth it is not in a position to generate any sort of profit. For it, expenses, which are workers' wages, are equal to gains. It follows that it has no profit. In the case of attempts to reduce wages, gains are reduced as well. The enterprise's supply curve is a perfectly straight, vertical line, and the producer can in no way influence real prices. The result is that the monopoly, not having any competitors, finds itself in perfect competition conditions. This leads to the obvious conclusion that a perfect competition market is a market where profit and economic growth are absent. It will be shown below that these conditions can be replaced by one condition. All that is needed and sufficient for perfect competition is that economic growth equal zero or that total producer profit be absent. For this, it is not necessary to have a sufficient number of producers or fulfill all the many other conditions.

As already noted, in the real economy, equilibrium and perfect competition conditions come about when, in practice, all producers achieve maximum possible effectiveness. Further increase to production becomes impossible. The economy approaches the limit of its productive potential. Profits rapidly shrink and economic growth fades. The economy is in a state of crisis. Where is the way out? Who or what will revive economic growth? Neither the government nor its officials are in a position to pull the economy out of the crisis. If the economy is at the limit of its productive potential, no sort of stimulation of demand can save the situation. If producers effectively use all available resources, then no flood of money can give rise to economic growth. Salvation will come from the side of ordinary producers, who are always striving to achieve profits. The sole possibility for extracting profit in this situation is increased productivity of labor and capital. This takes place by introducing innovations to the production process. These may be innovations in enterprise management; they could be new technologies, materials or fundamentally new equipment. In this way, the leader company, by preserving expenses (the right side of equation (2)) at the previous level increases the output of products (the left site of the equation). Profits are created. In order maintain equation (1), it is necessary that the cost of products be slightly reduced or that wages (or employment) increase. Both lead to losses for other enterprises. It is from precisely this moment that the market takes on the traits of imperfect competition. Such a state is unstable and in disequilibrium. The more enterprises that copy and implement the innovations, the greater the losses that are sustained by the remaining enterprises. The economic system trends towards a state of equilibrium and perfect competition, or, in other words, towards crisis. Economic growth and profits will exist until the last enterprise has implemented the innovation. This process has a distinctly expressed, wave-like shape: in the beginning it is characterized by dramatic growth and, when half the resources are used in production, economic growth achieves its maximum values, and then 
comes the fall. The cyclical changes in the economy were first connected with the introduction of innovations by J. A. Schumpeter, though he proposed that the reason for crisis was the very process of introducing innovations. (Schumpeter, 2007).

If we agree with the above-stated point of view, then the question inevitably arises: are crises truly characteristic only for free market systems, which many people inaptly refer to as capitalism? Obviously the economy can achieve the limit of its productive potential under any management scheme. If we look to the past, it is easy to see the many historical changes have economic causes. What are historical events such as the weakening of city-states, the decline of empires, the abolition of slavery and the transition from feudalism to capitalism? Both slavery and feudalism were, during their times, progressive socio-economic systems, but they ran their course and further development became inevitable. Further economic growth became impossible under the relations of production active at that time; increases to the prosperity of slave traders and feudal lords ceased: their profits, if you wish, trended to zero. There came a period of stagnation. An innovation that would create more perfect means of production and new forms of property was needed to overcome the crisis. Why then did the problem of crises only begin to trouble people at the beginning of the nineteenth century? It would seem that the answer is that crises began to take place more often. This was caused by the acceleration of economic growth in Europe and North America. (Barro and Sala-i-Martin, 2004). The tempo of growth in these regions at that moment achieved several percentage points a year, whereas thousands of years ago, according to many researchers, it didn't even reach a tenth of a percentage point. In the distant past, weak economic ties between countries and regions, the slow introduction of new technologies and difficulties in the exchange of experience and knowledge lead to slow, onset of change over the course of many centuries. For this reason, 100 or 1,000 years were required for a particular economy to reach the limit of its productive potential. Let us imagine the appearance of a new tool of labor that enabled the productivity of a particular piece of land to be increased by $10 \%$. The absence of roads, mechanical means of transport and printed publications and the undeveloped state of the market significantly slowed the spread of information and the exchange of experience. If only one of the hundred owners located in a particular region transitioned to using this new tool, then the average yearly tempo of economic growth would be $0.1 \%$. It would require 100 years for all the owners to implement the innovation. After 100 years the economy would have grown $10 \%$ and achieved the limit of its productive potential. Intensive growth of science and technology and development of the institution of private property created the conditions for the acceleration of economic growth. But the strengthening of ties between countries and continents and the free movement of capital made crises global.

If we agree with such a view, then the shortcomings in modern theories of economic cycles must be recognized. (Sawyer, 1985; Barry, 1979). Economic cycles arose with the first human being. And crises took place even when barter was actively used in society and money was non-existent and when people didn't even suspect the existence of such phenomena as insufficient demand and overproduction.

As noted earlier, economic growth occurs when producers generate profit and is reduced when profits disappear. What sort of connection is there between profit and economic growth? Is 
there a quantitative connection between the total profit of all producers and economic growth? How does the "invisible hand" of the market transform the profits of particular economic agents into increases in overall welfare? If answers to these questions can be found, then there will appear a sturdy bridge, which at the present day is quite precarious, connecting the two branches of one science: micro and macroeconomics. We will be greater able to judge macroeconomic phenomena on the basis of individual activities and the behavior of distinct agents. Let us try to find these answers.

\section{Profit and Economic Growth}

In a closed economic system, how can profits be generated by producers if, according to equation (1), expenses and the cost of final goods and services must be equal? This is possible because wages are paid at the beginning of the production process and products are sold after a certain period of time. Wages are spent on the purchase of commodities produced in the past and are payment for labor that will be expended on the creation of future commodities. Both at the beginning and the end of the production process, workers receive the full cost of their labor because the final product must be fully purchased. If an entrepreneur, after having introduced an innovation, produces more products from the previous amount of resources, then during the process of sale s/he will quickly see that more gains are being generated for a unit of commodity than were expended to produce it. What is the entrepreneur to do with these additional funds? There are two possibilities: the entrepreneur can purchase additional investment goods or use these funds in order to increase wages. But most likely, s/he will do both one and the other. Equation (1) will hold true because investment is additional labor payment in the industries connected with production of capital goods. Increased wages can lead to the desire to save part of one's funds. But saving does not violate the equation since it will be directed by borrowers towards purchases and investment. This is how profit, saving and investment come about in a growing economy. Many people might quickly argue that the equation can be violated because not all products are always sold and savings can be kept in a safe. It is understood that for various reasons some products might not be sold. This means that they have been removed from the exchange process and do not exert any sort of influence on economic variables and as such their fate, in the grand scheme of things, will not trouble anyone. Commodities will appreciate slightly: a phenomenon like inflation will take place. Savings that are kept in a safe also do not participate in trade. Such a form of savings merely reduces inflation and doesn't have any sort of effect on real economic values. It should be noted that savings and investment have no meaning under conditions of a steady-state economy because, as will be shown below, the interest rate in such an economy is equal to zero. One more note needs to be made with regards to remuneration of labor. Obviously, labor should receive compensation equal to average productivity. Because of this, effective enterprises will generate profits and ineffective ones will experience losses. It is not difficult to understand why profit precisely equals economic growth. This follows from equation (1): an increase in productive labor (dw) leads to an identical growth in output.

$$
\mathrm{d}(p Q)=L \mathrm{~d} w
$$


We must bear in mind that $d w$ is the average increase in production for all workers. At the beginning of the production cycle, wage workers receive wages that correspond to their productivity during the previous cycle. They can purchase all the commodities produced. If in the new cycle their labor productivity increases, then the owners of the means of production receive profit. Because of this the right side of the equation represents enterprises' total profits and the left part represents economic growth. All profits inevitably go into increasing labor compensation for wage workers. After having had profits in their hands for a certain time, entrepreneurs direct them towards investment, increasing wages in the capital goods sector, or purchase consumer goods, increasing wage compensation at enterprises that produce a final product.

Everything is even simpler in economies without money. In this case the only possibility for materializing profits is acquisition of additional investments or consumer goods, which come about as a result of economic growth. Profits are only generated by an entrepreneur when s/he produces additional commodities. S/he can exchange them for some additional amount of consumer or investment goods. In a barter economy, any difference between the concepts of "profit" and "economic growth" disappears: they are indistinguishable. The very words that represent these concepts become in practice, synonyms. If there is no increase to the output of products and services, then the total profit of all economic agents equals zero. Any additionally produced quantity of products is profit for somebody and this means that total profits is equal to economic growth.

In order to check once more that the conclusions that have been made are correct, we'll take a look at a very simple example. Three producers are interacting on the market, all three of whom use one factor of production: labor, in the amount of one unit. Use of several factors doesn't fundamentally change anything in the argument, but does slightly complicate it. Since what's important for analysis is not absolute but relative prices, we'll assume that prices for final products are constant and only the price of the factor changes. The output of a certain enterprise could be represented in the following form:

$$
p q_{i}=w_{i} l_{i}
$$

where $p$ is the price of a commodity, $q_{i}$ is the quantity of commodities produced by each company, $i$ is the number of the enterprise $(1,2$ or 3$), w_{\mathrm{j}}$ is the price of a factor of production and $l_{i}$ is the quantity of factors of production (in our case $l_{1}=l_{2}=l_{3}=1$ ). In a state of perfect competition, when economic growth and profits are absent, the price for a factor of production is, let's say, 60 conventional units $\left(w_{j}=w_{0}=60\right)$. The production of each company will be 60 of a certain unit and overall production will be 180 . Let's assume that the first company does not want to accept the absence of profits and introduces an innovation that 


\section{Macrothink}

Business and Economic Research

ISSN 2162-4860 2012, Vol. 2, No. 2

enables it to increase production by a third without changing expenses. Then the state of the economic system changes slightly. The first company can generate a profit $\left(v_{1}\right)$.

$$
\begin{gathered}
p q_{1}=w_{0}+v_{1}, 90=60+v_{1}, v_{1}=30 \\
p q_{2}=w_{0}=60, v_{2}=0 \\
p q_{3}=w_{0}=60, v_{3}=0
\end{gathered}
$$

Total output at this moment is 210 conventional units, and economic growth is $30(210-180)$. Total producer profit is equal to economic growth and is 30 units. At first glance, the indicated equilibrium will hereafter be violated, since the first producer will continue to take in a profit but cannot increase production. But this is not the case because the situation will change on the market for factors of production; the first company will direct all gains towards acquiring factors of production. All funds, which is 210 conventional units, go to purchasing the three factors of production, the price for which $\left(w_{1}\right)$ will be 70 units. The second and third producers will begin to suffer losses, since they cannot use resources as effectively as the first.

$$
\begin{aligned}
& p q_{1}=w_{1}+v_{1}, 90=70+v_{1}, v_{1}=20 \\
& p q_{2}=w_{1}+v_{2}, 60=70+v_{2}, v_{2}=-10 \\
& p q_{3}=w_{1}+v_{3}, 60=70+v_{3}, v_{3}=-10
\end{aligned}
$$

Production has not changed and is 210 conventional units, economic growth is absent. The amount of producer profit is equal to zero and the equilibrium between growth and profits has been maintained. Let us assume that the second and third producers don't want to accept losses and introduce advanced technologies at their enterprises. The companies' situation takes on the following form:

$$
\begin{aligned}
& p q_{1}=w_{1}+v_{1}, 90=70+v_{1}, v_{1}=20 \\
& p q_{2}=w_{1}+v_{2}, 90=70+v_{2}, v_{2}=20 \\
& p q_{3}=w_{1}+v_{3}, 90=70+v_{3}, v_{3}=20
\end{aligned}
$$

The system's GDP is equal to 270 units, growth is 60 and amount of profits is also 60 . Equilibrium has been maintained. All resources are used with maximum effectiveness and 
further growth is impossible. The system has come to a state of perfect competition and the next crisis. During the next production cycle, the price of utilized factors of production is 90 units (270/3). Production is maintained at the previous level and profits disappear. The market is plunged into a state of crisis and producers undertake the search for the necessary innovations that will increase the productivity of implemented resources.

Let us take a detailed look at a more realistic case in which there are two factors of production, labor and capital, as well as a large number of producers. For simplicity of presentation, let us assume that companies produce one type of consumer goods. Part of the producers creates consumer goods, and they employ $L_{1}$ workers. The second part of the companies is occupied with production of capital goods and they employ $L_{2}$ workers. Total output in perfect competition conditions is the total cost of factors of production.

$$
p Q=w L_{1}+r K=w L_{1}+w L_{2}=w L_{r}
$$

where $p$ is the price of a commodity, $Q$ is the quantity of commodities (this can be represented as the sum of all commodities produced by the companies $Q=\Sigma q_{i}$ ) $w$ is the price of labor, $L$ is the total quantity of labor (this can be represented as $L=\sum l_{i}$ ), $r$ is the price of capital and $K$ is the total quantity of capital (this can be represented as $K=\Sigma k_{i}$ ). The output of a particular company in a steady-state condition is represented by equation (2). Expenses (the right side of the equation) are equal to returns (the left side of the equation) and profit is absent. Innovations are needed in production and management in order to change the situation and break free from a state of perfect competition. If this takes place, then after a period of time $d t$ a company will increase production and receive a profit without changing its expenses:

$$
p q+d(p q)=w l+r k+v
$$

where $v$ is the company's profit for a $d t$ period of time. Taking (2) into account, we get the following:

$$
d(p q)=v
$$

Growth in the production of a particular company is equal to the profits received thanks to effective and productive use of resources. After summing the output of all enterprises, we get the following for the economy as a whole:

$$
p Q+d(p Q)=w L_{1}+r K+\sum v_{i}=w\left(L_{1}+L_{2}\right)+\sum v_{i}=w L+\sum v_{i}
$$


Taking (3) into account, we get the following:

$$
d(p Q)=\Sigma v_{i}
$$

The last equation confirms that economic growth is equal to total producer profits. Both the quantity of a commodity produced and the price for it may grow. This depends on how profits are used. Profits can be directed towards investment in production or towards consumption. A very interesting conclusion follows from this: higher inflation should be seen in countries with a poor investment climate and undeveloped market institutions than in successful countries. Increased inflation should also have a place in the period of declining economic growth. Such periods see a reduction of profits and strengthened competition. Many entrepreneurs do not see a possibility for effective investment and part of ready assets are directed towards the consumer goods market, which leads to price growth. Taking a look at the available statistical data shows that such observations are completely realistic.

There is yet one more important question that needs to be cleared up: how are prices formed on the market? As is known, the price formation process always involves the participation of two parties: producers and consumers. As noted by many researchers, in the case of price formation for one of its commodities, a producer holds to the principle of "costs plus a certain markup." (Eichner, 1985). This principle should be acknowledged as reasonable, taking into account that the given producer uses resources more effectively than the average producer on the market. In such a case, the markup is its rightful profit. But ineffective producers are also guided by the exact same principle, and they don't even think of using a principle of "expenses minus markup." Consumers will agree to the proposed price only in one instance, if there is inflation in the economy. Total producer profit cannot exceed economic growth and inflation enables equilibrium to be maintained. The nominal values of profits might be positive for all producers, but in practice this can never be the case with their real values. Ineffective enterprises will inevitably suffer losses, which forces them to improve their management and implement new technologies.

What guides the actions of consumers in accepting or rejecting proposed prices? Let's assume that our commodity is certain capital goods and that our consumer is a producer who is using these goods as a production resource. The producer strives to take in a profit. S/he uses a certain price as a reference point, above which s/he will not purchase the resource. As follows from equation (2), in conditions of production growth with constant capital

$$
w=\frac{d(p q)}{d i}
$$

With an unchanged quantity of labor and cost thereof

$$
r=\frac{d(p q)}{d k}
$$

The price for a factor of production is equal to its marginal product. This is how labor and capital are appraised by an individual entrepreneur or owner of means of production. The 
internal price of the factor for said entrepreneur is equal to the increase in output created by acquisition of yet another unit of the resource. Since the cost of additionally produced commodities is equal to producer profit, then it is obvious that price is defined by profit received after acquisition of another unit of the resource. Internal price does not always match market price; in fact, they practically never match with the exception of in the conditions of a steady-state economy. In the example examined above with three producers, the internal price of a unit of labor for the effective producer was 90 units while for the ineffective it was 60 . The market price equaled 70 units. In the case that internal price is higher than the market price an enterprise will generate profit and strive to purchase additional resources until the time that prices balance out. If internal price is lower than market price, then such a producer will experience losses. S/he will have to increase the productivity of resource use and in this way increase the internal price of that resource.

And what guides an individual consumer that purchases commodities on the market? S/he appraises commodities in the exact same way that an enterprise appraises resources. The consumer will purchase additional professional training if expenses on it are lower than profit received in the form of additional payment for his/her labor. S/he will purchase a car if the cost of maintaining it for the entire period of use is lower than the value of the additional utility which takes the form of additional free time and a higher level of comfort. Consumers, like entrepreneurs, appraise the amount of potential profits from acquisition of a commodity and in this way determine their own internal price for it. The market, summarizing everyone's opinions, establishes a unified market price for a commodity or service. Under this approach, the marginal utility of a commodity is expressed as the consumer's internal price for this commodity and the total utility for a certain quantity of commodities is the internal price multiplied by the quantity of this commodity. Perhaps everything that has been said sounds a little unusual and unconvincing, but what's even more unconvincing is the suggestion that an entrepreneur strives to maximize profit during the day and then in the evening heads to the mall and tries to maximize utility, which cannot be quantitatively measured. On these extremely shaky grounds, operating only on intuition, s/he determines what price s/he finds acceptable, which is expressed as a concrete number. Even stranger are the attempts to correct this situation using consumer indifference curves. (For example: Samuelson and Nordhaus, 2004). On the one hand, we can agree with the impossibility of quantitatively appraising the value of utility, but on the other hand, we can assert that an equal sign can be placed between the utility of two commodities. In any case, a consumer, whether guided by utility or profit received, determines the price that $\mathrm{s} / \mathrm{he}$ finds acceptable for a certain commodity. By comparing one's own appraisal with the market price, a consumer makes a decision about whether to purchase or turn down a product. Attention must be given to one interesting fact that results from equation (2). In steady-state conditions, when profits and economic growth are absent, the price of labor and capital cannot be determined: there is one equation and there are two independent variables. When the economy is at the limit of its productive potential, it becomes impossible to establish the price of a resource because the resource's marginal product disappears. The economy doesn't grow, additional resources are not purchased and profits disappear. What does a factory cost if it doesn't generate profit? What is the price for a piece of land if, regardless of its use, we can only recuperate our losses? 
In diagram 1 are presented the total profit before taxation of US corporations and the yearly change in nominal GDP for the period from 1940 to 2008. The absolute values of total profit and economic growth, in a rare exception, are not congruent, but the shapes of the curves are in many ways similar. The maximums and minimums for corporations' earning power correspond with the maximum and minimum changes to GDP. If we agree with the conclusions presented above, then we must at least try to explain the difference between total producer profit and economic growth.

There might be several reasons for this difference. The first that comes to mind is taxes paid by corporations from profit to state and federal budgets. Does it make sense to subtract taxes from profit? There naturally arises a desire to quickly respond "yes." Corporations' profit is reduced and producers expend less on investment and expanding production. On the other hand, taxes in the end are used to make government purchases and transfer payments. This likely shouldn't break the equilibrium between profits and economic growth for the reason that nothing prevents us from thinking that corporations make such expenditures of funds voluntarily. Whether producers take such steps voluntarily or involuntarily is completely insignificant for analysis. Yes, it is possible that such required expenditures are ineffective, but this only leads to an increase in inflation, since such redistribution of funds increases demand and reduces economic growth. We will only see total profits for corporations exceed changes in GDP if we do not account for the losses of som producers or (and) if we underestimate the output of goods and services.

Government bodies that receive taxes are the same sort of economic agents as common corporations. If we agree with this view, then their activities must be regarded in exactly the same way as those of usual producers. It is obvious that the expenses of government bodies greatly exceed their output expenses. Expenses are equal to all taxes paid, while the set of services that the government produces are essentially free. As such, the government is an extremely unprofitable producer. Its losses might be the cause of the difference observed. Additionally, the activities of corporations on the securities market are in no way reflected in GDP calculation, which creates additional difficulties. The results of such operations inevitably influence an enterprise's current profits. If we also account for the fact that many financial statements are unreliable and radiate unwarranted optimism, then the difference between profits and economic growth can be fully explained. Obviously more thorough analysis and further discussion regarding the available data is required. 


\section{Diagram 1.}

GDP growth per year,

corporate profits, mld dollars

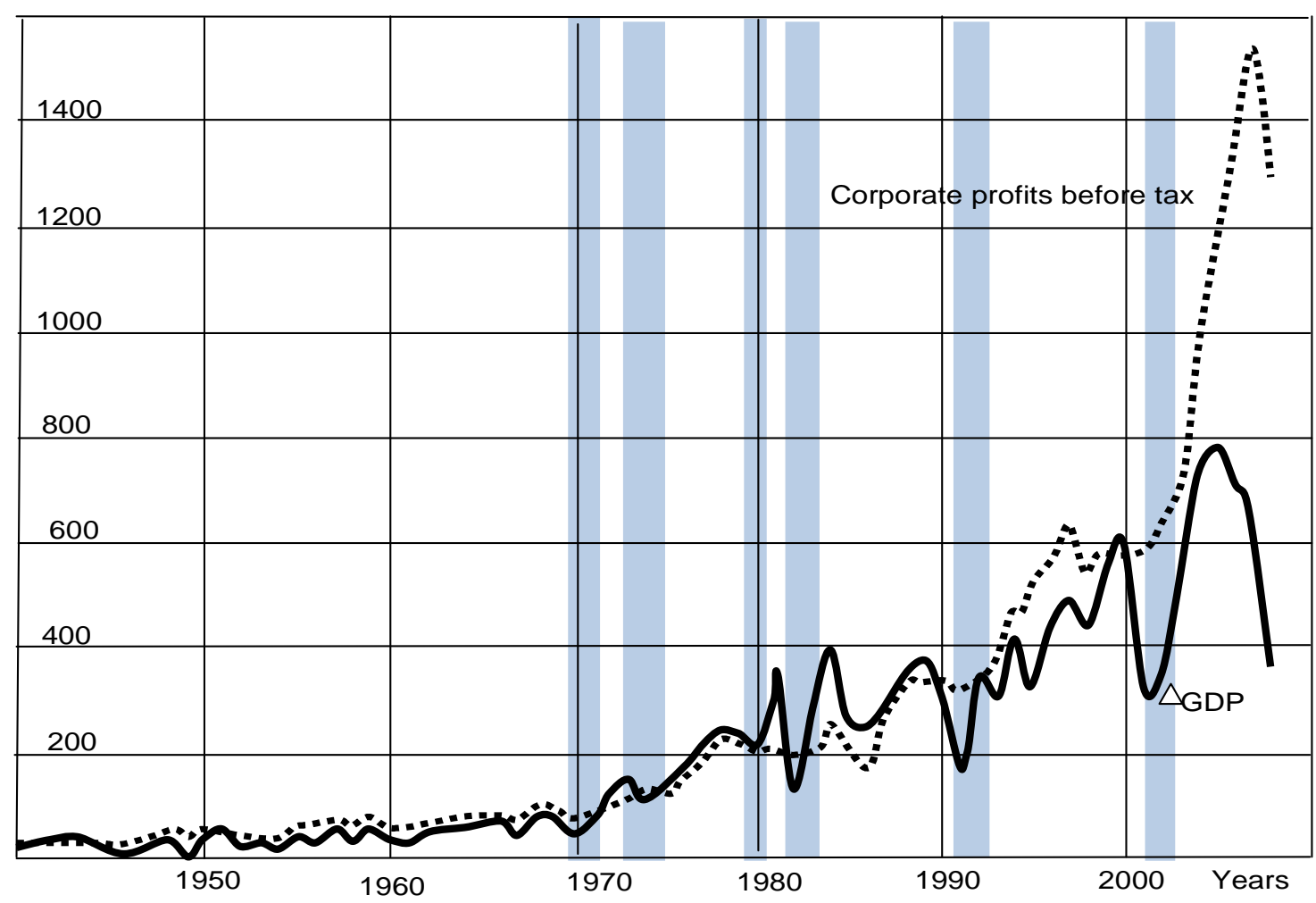

Source; Bureau of Economic Analysis. U.S. Department of Commerce.

\section{Economic Cycles}

In approaching the debate of economic cycles, it would probably be a good idea to try and answer the following question: why do crises occur so irregularly, why do profitable and tranquil periods sometimes extend for several decades and at other times for just a few years? Why was the long, post-war period of successful development replaced by the rocky ' $70 \mathrm{~s}$, which included as many as two whole crises and were followed by another at the beginning of the '80s? If we assume that the onset of a crisis takes place when the economy is approaching the limit of its economic potential, then why are such varied periods of time required to achieve said limits? There's no doubt that different innovations are variously effective. There is technology that increases productivity of implemented resources by $10 \%$ and there is other technology that increases productivity by $20 \%$ or $25 \%$. Additionally, copying cutting edge innovations sometimes involves significant complications while at other times it doesn't require any sort of capital investment or increases to personnel qualification. It follows that the time required for applying an innovation is completely different in different cases. Telephone communication and the Internet significantly expanded the potential for receiving information, reduced the time required to search for needed goods and services and enabled contracts to be concluded without leaving one's home. This made it possible to significantly reduce expenditures and increase labor productivity, but there is no basis for making the assertion that these increases were identical with the introduction of telephone 
lines and the appearance of the Internet. Additionally, various amounts of time were required to introduce the indicated innovations. As such, economic cycles have varied lengths and the maximum value of real economic growth varies between cycles. At the beginning of each economic cycle the economy has a diverse collection of innovative solutions that make each cycle unique. The question naturally arises: why does the economy achieve the limit of its productive potential? It's obvious that in the period of declining economic growth when the majority of enterprises have already implemented new technologies, the reduction of profits and toughened competition should force entrepreneurs to search for new ways to increase labor productivity. Why doesn't this take place? It does, in fact, take place, but not very often. The long post-war period of successful development was evidently connected with the appearance of a large number of new technologies, the creation of new materials and the emergence of completely new branches of industry. The intense development of science and technology at that time enabled the advent of the television, atomic power plants, commercial air transport, space satellites, microelectronic apparatuses and much more. This period saw periods of both economic growth and decline, but at the moment when the economy approached the limit of its productive potential, when competition on the market increased, entrepreneurs consistently found ways to use resources more effectively. Such entrepreneurs temporarily held monopolies, receiving solid profit. The others rushed on behind, imitating those successful entrepreneurs and adopting cutting-edge management and production techniques. Economic growth accelerated and achieved its maximum, when half of the available resources were used with maximum effectiveness, after which followed a new decline. Things continued in this way until the start of the "70s. The problem is that substantial discoveries and significant technologies don't turn up every day. Their implementation and introduction to the production process usually requires great amounts of effort and time and significant expenses and is connected with certain risks. There are no guarantees that expenses will pay off. This is why, during successful years, when enterprises are turning a profit, risk doesn't always seem justified to the entrepreneurs. It's much simpler to buy up ever cheaper resources and expand production. In this case, a profit is guaranteed.

In diagram 2 are shown changes in US GDP (percentage), unemployment (percentage) and inflation (percentage) for the period from 1965 to 2002. In the second half of the ' 60 s, real economic growth in the US steadily declined and the economy approached the limit of its productive potential. Competition on the market increased, the struggle for resources gave rise to an increase in salaries and decrease in unemployment, which, in turn, lead to increased inflation. Producers were required to increase the prices for their goods and services. The reason for this was the natural reduction of profits. Investment programs were deployed and required financing and enterprises were required to increase the prices of their products. The use of loan resources served, to a certain extent, as an escape from this situation, but other problems arose. At the moment when the loan agreement was concluded, the director of an enterprise saw the lending terms as fully reasonable. But it quickly became apparent, that real profit was constantly declining and funds clearly weren't sufficient for repaying loans. The sole way out was to increase prices for goods and services produced. All periods of declining economic growth are characterized by growth in inflation and employment (1962-1970, 1973-1974, 1978-1980, 1986-1990, 1999-2001, 2006-2008). It is during precisely during 


\section{Macrothink}

Business and Economic Research

ISSN 2162-4860

2012, Vol. 2, No. 2

these periods that the relationship between inflation and unemployment takes the form of a classic Phillips curve (diagram 3).

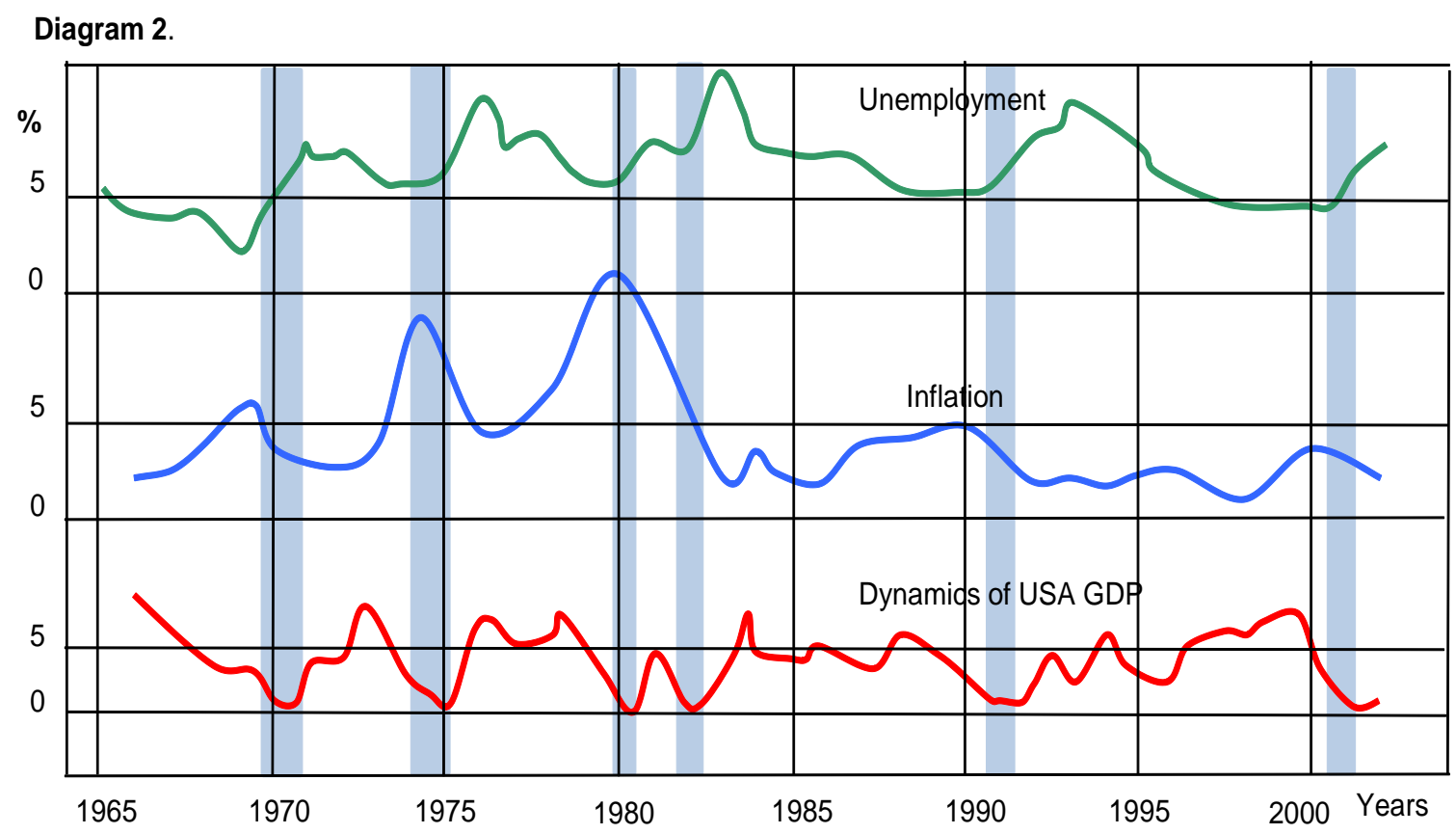

Source; Bureau of Economic Analysis. U.S. Department of Commerce.

\section{Diagram 3.}
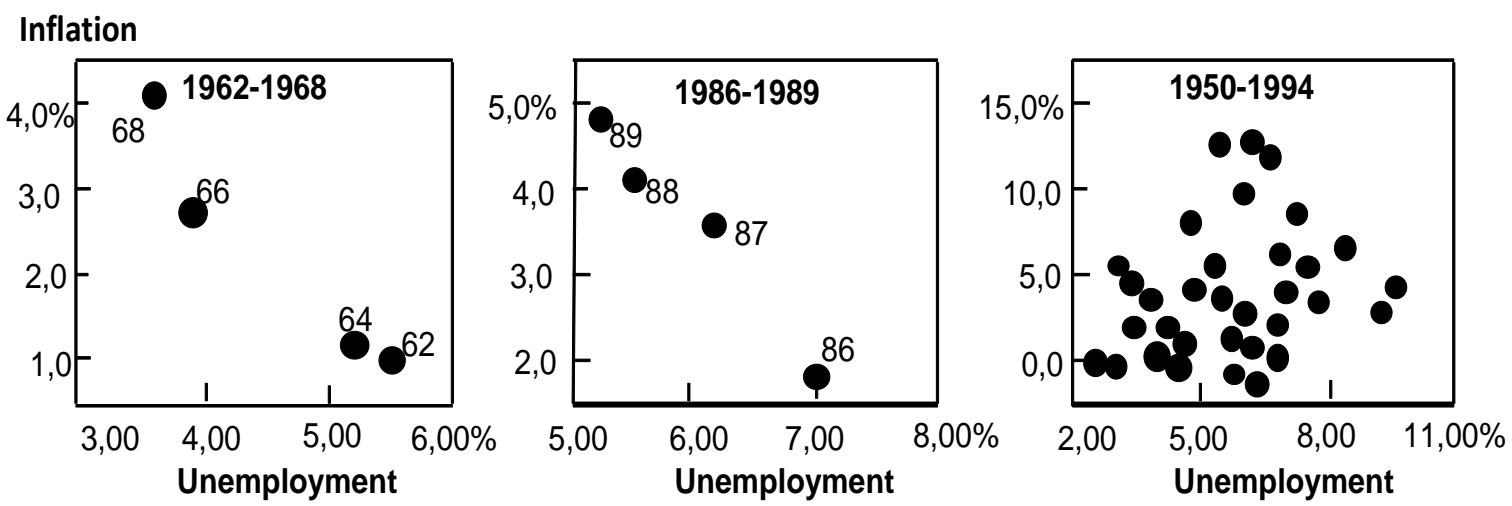

In periods of economic growth or full stoppage of economic growth, the indicated relationship takes on a more complex character. When the first signs of crisis appear in the economy, inflation, having achieved a certain maximum value, quickly begins to be reduced and unemployment, having reached its minimum, begins to grow. The reason for such phenomena can be found in the serious reduction of enterprises' profits, which leads to catastrophic reduction in investments. Enterprises cease to expand production and cut back on the hiring of new workers. Moreover, in an attempt to retain at least some profit, producers are required to reduce costs, which inevitably leads to layoffs and the growth of unemployment. As follows from equation (1), reduction of the wages fund should give rise to 
deflation or a fall in production and, potentially, to both. Sometimes this is what takes place, but here a lot is dependent on government actions. As a rule, the universal means for attempting to fix a crisis is to allocate additional funds, which somewhat increase inflation. Does this help in the struggle with unemployment? Most likely, yes. In crisis conditions, when markets are in a state of perfect competition, ineffective enterprises, who utilize resources at a level of effectiveness that is lower than the market average, suffer more than others. Additional funds enable them to halt the fall of production and retain the number of staff. But such help is sensible only in the case that the enterprise can increase its productivity after a time. If this doesn't happen, then its fate is sealed. Additionally, there remains doubt not only regarding the effectiveness of such help. For more successful enterprises, such nonmarket intervention could give rise to justified indignation. They demonstrated their superiority in a fair fight and it is possible that they could've bought up their unsuccessful competitor or taken on its clients. The government, using nonmarket means, nullifies the market advantage they have received, though fairly good goals serve as the justification for this. To what extent do attempts to avoid temporary unemployment and the reduction of production justify such steps? Doesn't this give way to impunity and irresponsibility? During periods of crisis, many banks and their investment branches experience financial difficulties and, inevitably, receive help at the expense of taxpayers. What makes them give out risky loans and engage in dangerous operations on the stock market? Obviously it is not only high profit but also confidence in the fact that, in the case of a problem, help will inevitably be forthcoming. And if they didn't have such confidence, then maybe there would be less of such problems. One of the justifications for such senseless behavior on the part of companies is the regulation of interest rates by financial authorities with the goal of stimulating economic growth. Jumping ahead for a moment, it should be noted that interest rates are determined by average producer profits and are equal to economic growth expressed as a percentage. By artificially reducing the interest rate, the authorities make loan resources more available not just for effective producers. This is extremely dangerous, particularly in a period of declining economic growth. Growth decreases for natural reasons: there are ever fewer ineffective producers on the market and as such there is similarly less opportunity for more productive use of available resources. Profits are reduced and the level of competition grows precipitously. Loan repayment becomes a problem for successful enterprises and for less successful ones this problem can become insoluble. Things end up working out so that we create problems for ourselves and then heroically try to solve them. Maybe we would be better off if we didn't overestimate ourselves and agreed that the free market is the best medicine.

As a rule, periods of economic growth see moderate inflation and retain a fairly high level of unemployment. Such a state of affairs is fully explainable. At the very beginning of growth, only certain entrepreneurs can see totally new potentials for growth. Perhaps these entrepreneurs have extraordinary capabilities. Perhaps they are surprisingly lucky. Perhaps the simply were in the right place at the right time. In any case, enterprises that have managed to produce more products than other enterprises from the same amount of resources will temporarily hold a monopoly and receive their well-deserved profit. Competition on the markets at this time is weak, and because of this inflation is moderate. Production is 
expanding by miniscule increments and as such unemployment is fairly high. Additionally, the new methods of production and management could require specialists in a different field or workers with different qualifications, which leads to structural unemployment. A very short time passes and entrepreneurs become all the more convinced of the need to implement the new technologies. Entrepreneurs not only copy the cutting-edge technologies, they improve upon them as well. This allows for increased profit and expanded production. But competition inexorably grows, profits decrease and economic growth is reduced. The economy rapidly approaches a crisis and a state of perfect competition. The exit from the crises of the "70s was creation of a large number of energy and resource saving technologies. Vehicles became lighter, engines much more economical, new materials became available and serious advances were made in microelectronics that led to the emergence of new and improved home appliances as well as automated industrial systems. Ever fewer resources were required for creating a unit of product, profits grew and investment increased. In the ' 80 s, personal computers were widely distributed, which undoubtedly enabled escape from the next economic crisis. Expenses on warehouse and financial accounting and on financial analysis were significantly reduced by the appearance of computers. It became possible to exercise a quicker and more responsive control over all the business operations at any enterprise. During the '90s, software was further perfected and computers became many times more powerful. Additionally, during these years there was intensive growth in cellular communications and the Internet. Information began to spread instantaneously and the amount of it increased sharply; telephone communication became possible anytime, anywhere. The growing effectiveness of management and control and the declining cost of receiving information enabled practically an entire decade to go by without a crisis. Crises are inevitable, but they are necessary for us to steadily increase our productivity, perfecting the production process and introducing innovations. Crises are inevitable, like the coming of springs and summers. To believe they are caused by the actions of an incompetent government, the greed of entrepreneurs or the irrational behavior of consumers is just as ignorant as to blame birds flying south for the onset of winter.

Several words must be said regarding the reasons for the global nature of modern crises. Hundreds or thousands of years ago, crises weren't global in character. The crisis of feudalism came to various countries at different times and the flowering and decline of cities, governments and empires did not take place simultaneously. Weak economic ties and difficulties in the exchange of information and knowledge isolated the economies of various regions. Scientific discoveries and new technologies spread very slowly. In one part of the world people used metal tools for labor and in another they continued to hunt using stone axes and arrows. The high cost of transporting raw materials and final products lead to significant differences in the price of the same product in different countries. This is the reason why economic development in each region had its own particularities. It must be noted that conquest of territories and formation of the colonial system were necessary in order to receive commodities and raw materials at lower prices, which made it possible to extract higher profits and successfully develop. At the current time, when the price of oil in China, Africa, South and North America is practically identical, wars and conquest of colonies is absolutely senseless. Moreover, the existence of state borders, which complicate 
the movement of people, goods, services and capital, diminishes economic growth and slows the development of the world economy. The European experience with unification will soon be utilized in other parts of the globe and closed economies will go extinct like the dinosaurs or become more open. The free movement of capital, people, knowledge and new ideas will equalize economic growth in various regions. This will take place just like the equalizing of profits on various markets. Resources and capital trend towards those places where profits are higher. The rates of growth in various markets and countries will even out and they will simultaneously reach the limit of their productive potential, and for this reason a crisis will simultaneously commence in countries and parts of the world. A globalized world will inevitably give rise to a globalized crisis, but there's absolutely no need to run through the squares destroying governments and the malls of world-renowned companies. These companies made worldwide enlightenment and progress possible, their services were directed towards making all of us wealthier and happier. And each of us that is looking for somebody to blame for our unhappiness and thanks God for sending him wealth needs to recall the existence of equation (1). Any profit gives rise to economic growth, which, in turn, makes everyone wealthier; our incomes grow at the exact same tempo as production. Our incomes are precisely equal to the total cost of consumer goods and services. Global corporations have vested interests in increasing our incomes. Otherwise they will be unable to sell their additionally produced commodities or will be forced to reduce the prices for them.

\section{Rent and Interest}

What new perspectives can the proposed connection between profits and economic growth bring to discussions of such concepts as rent and interest? If we agree with the widely shared opinion that there is a close tie between profits and the size of interest (Samuelson and Nordhaus, 2004; Minsky, 1978), then the argument presented above presents much that is new. Indeed, there are two circumstances that likely prevented a firm connection from being established between profit and interest. First of all, as observed in the real economy, entrepreneur profit is characterized by surprising volatility. One enterprise, a monopoly, for example, takes in high profits, while others can barely make ends meet or suffer losses. Everything depends on the level of competitiveness on the market. On the other hand, the amount of interest, in contrast to profits, is fairly stable and can stay the same for a long time. Second of all, loans are taken not only by producers, but by consumers as well. Why do they agree to the existing interest rate though they don't receive a profit? If they are pressured into doing so because the loans market is formed primarily by producers, then why are they ready to make savings and why do they consider the interest paid them to be fair? Now, taking into account the connection between profit and growth, it is simple enough to explain the existence of interest and the amount of it. Indeed, an entrepreneur receives loans, organizes the process of production and after a certain time extracts a profit. Part of this profit, and in extreme cases all of it, can be paid out in the form of interest. Interest is defined by the market and for this reason it is defined by average profit. And average profit, as shown above, is far from a random value. Average profit, expressed as a percentage in relation to expended assets, is equal to economic growth also expressed as a percentage. Economic growth and average profit, in contrast to the profits of individual producers, are fairly stable and 
predictable. In periods of economic growth they steadily grow and in periods of decline they also decline. Furthermore, their real values are also reduced while their nominal values might remain the same or even grow, the cause of which is growing inflation. The profits of effective producers exceed average profit, and for this reason loans are available to them. And this is fair, they have an opportunity, using loans, to purchase resources from more effective producers and increase their output. Loans are unavailable to ineffective producers until they cannot increase their productivity. And this should make us happy if we want for resources to be used in the most productive way possible.

Regarding producers, as follows from equation (1), increases to their expenditures are equal to the value of economic growth. This is how things should be if we want the equation to hold true after increases to the output of producer goods and services. Consumers, like producers, receive profits that take the form of increased expenses. Consumer profits, like producer profits, are equal to economic growth. It follows that consumer profits are precisely equal to producer profits. Because of this, the interest rates for consumer loans and loans granted to producers are established at the exact same level. Consumers agree to save and producers to invest. The opposite assertion is true as well: producers can save and consumers expend on acquiring additional commodities and on becoming entrepreneurs and investing in production. Obviously the interest rate is equal to economic growth expressed as a percentage. Any person, by saving or offering his funds to someone in the form of a loan, is guided by the following consideration: my money might be put into production and bring a profit, my money might reach a common consumer, whose wages will have to grow in the future. As such, by refraining from consumption today, I can demand some sort of compensation in the future equal to average profits or average increase in expenditures. Since economic growth is equal to total profits or total increase in expenditures, it's fair if I lose interest equal to economic growth expressed as a percentage. The borrower, obviously, should also not object.

It goes without saying that interest rates in the real economy are subject to oscillations that are connected with changing supply and demand. Additionally, we must take into account the active role that is played in this market by state bodies concerned with the problem of economic recessions and excessive optimism that, in the opinions of many, gives rise to the formation of dangerous economic bubbles. More often than not, the available statistic data speaks in support of rather than in opposition to the stated proposals regarding the equality of interest rates and economic growth. In any case, catastrophic differences between real interest rates and real economic growth are not to be found. Several questions arise only in connection with unreasonably high interest in the distant past. If we agree with the opinion that real growth hundreds of years ago created a share of interest, then there arises doubt regarding the justifiability of interest rates of $20 \%, 10 \%$ and $5 \%$ that existed at that time. In connection with this, the following must be state: in the era of feudalism and early capitalism, the loan resources market was in its infant stages; it had only just begun to take shape. Trader and producer profits were small and extremely unstable. Any entrepreneurial activity was a risky and very dangerous act. There was real danger that contracts concluded would not be fulfilled, and not just for economic reasons, but also in connection with the unexpected outbreak of war, the untimely death of debtors or common robbery. A merchant or 
moneychanger could make a profit by setting an interest rate that would take into account all the various risks. Naturally, this interest would be fairly high and would be inaccessible for the large part of the population. For this reason, society primarily had a negative attitude towards people who were involved in providing loans and who took funds on loan, paying interest to their owners. It's well known that Christianity considered such activity to be a serious sin. But as market relations developed, loans became all the more accessible and nowadays banking is a highly respected and honored profession.

Loans can be provided not only in the form of money, but also in the form of various material resources: land, means of production and material stock. Interest can be repaid in the form of a particular amount of the commodities produced or services provided. In this case, interest becomes rent and there is no sort of significant difference between the two. It follows that interest is not a monetary phenomenon: it also exists in barter economies in the form of rent. Both rent and interest are defined in the amount of average profit and are equal to economic growth. If we suggest that this is not the case and that rent is, say, less than interest, then landowners will have more profitable options than renting the land plot. S/he could sell the plot of land, place the money received in the bank and receive a higher profit in the form of interest. The sale of land plots to other owners leads to a reduction in the cost of land; rent, remaining constant in its monetary value, increases relative to the cost of land. Interest, rent and economic growth will correspond with one another. If rent exceeds interest, then demand for plots of land will increase the price for them. In this way, rent becomes precisely equal to interest.

More than 120 years ago, in his work Capital and Interest, Bohm-Bawerk, in criticizing Marx's theory of exploitation and surplus value, gave what is in my opinion an extremely apt example that reveals the nature of interest. In his example, over the course of 5 years, a worker labors to create a steam turbine with a value of $\$ 5,500$. There is no objection made, he writes, to the fact that for his five years of labor the worker should receive all $\$ 5,500$. But when should he receive this payment? Obviously at the end of the five years. The worker cannot be paid while the turbine is still not prepared and not sold. But he can't wait that long, he needs to purchase the means of existence. At the completion of the first year, he requests compensation for his labor. The question is, how large should the payment be. Should it be $\$ 1,100$, since the worker has fulfilled a fifth of his work? Bohm-Bawerk's response is "No." The turbine still won't be ready for another four whole years. Our worker will not receive the full cost of a fifth of the turbine, but less than that. The reason for this is the existence of interest. Applying the level of interest of 5\% that was prevalent at that time, Bohm-Bawerk concludes that at the end of the period the worker should receive $\$ 1,000$. Indeed, we can look at this in a slightly different way: the worker wants to receive loans, which he pays back after five years. After five years he can pay $\$ 5,500$. It be very strange if every year he received $\$ 1,100$. And where is the exploitation here? Surplus value is the interest paid to the worker for the loan he is presented with. In Bohm-Bawerk's example, loans are offered by the owner of an enterprise, and this means that he should be the one receiving the interest. For the owner, interest is profit. The owner receives profit in the amount of 5\% per year of the amount of funds invested; the interest level is 5\%. It should be noted that if all producers 
have such profit, then economic growth in the country is $5 \%$ and employee wages increase by $5 \%$ annually. There is no sort of exploitation to be found; workers receive the full value of their labor at the beginning of the production process and entrepreneurs and owners receive it at the end if they effectively use the resources and increase production. And so, the wolves are sated with the sheep still in one piece.

\section{Conclusion}

Equality between total producer profit and economic growth in a closed economic system inevitably results from the equality between the total wages of all workers and the cost of all the consumer goods and services produced. If the final equation did not hold true and wages were, let's say, lower than the values of all commodities, then not all commodities would be sold. Producers would be forced to reduce the price of their commodities and because of this equality between enterprises' gains and the total wage fund would quickly be restored. If we propose that wages exceed the cost of commodities produced, then this could mean that expenses at several enterprises exceed their incomes. It follows that these producers will need to reduce wages, which restores the balance that was violated. It goes without saying that producers use not only labor but capital as well, the cost of which is equal to the cost of the labor expended to produce it. The labor theory of value is correct. But where here is the profit and where is the exploitation? Producers receive a profit when they use available resources more effectively than other market participants. Having purchased resources at the beginning of the production process for a price equal to their average productivity, and having paid workers monetary compensation according to their average productivity, the entrepreneur will have more products than before at the end of the production process. After selling a commodity the entrepreneur receives gains that exceed expenses. The profit received is precisely equal to the cost of the additionally produced commodity. The total producer profit for the market as a whole will equal economic growth. The appearance of profit does not violate the equilibrium between the cost of all commodities and the wages of all workers. An entrepreneur has several means for expending income. The most natural of these is investment. In this case, all profit goes to additional labor payment in the industries for production of capital goods, and for this reason the equation will hold true. It is easy to note that the equation remains in force regardless of how profits are used. Profits can be directed towards savings, but they will come to other producers or consumers through the loans market, and these producers and consumers will use them for investment or consumption. A successful entrepreneur can direct profit to additional wages for its workers or personal consumption, which also does not violate the equation. It is only the last of the indicated means of using profits that enables one to suspect the existence of several forms of exploitation. For this reason, the following should be noted. First of all, this should be recognized as the most exotic and least likely use of profits. Indeed, if an enterprise generates profits it means that it uses resources more effectively than other enterprises. By directing all its profit into the purchase of additional resources, an enterprise can increase its profit still more. For this reason, increased investments are, in this case, the most rational and reasonable decision. In the second place, even if owners of the means of production or entrepreneurs spend all profit on personal consumption, this still does not mean that they are 
appropriating the product of somebody else's labor. The introduction of new technologies and improvement of management and control over an enterprise are primarily attributable to the entrepreneur. As such, it is only right that s/he allocate part or all of the profit. This in no way reduces the prosperity of the entrepreneur's workers: they can purchase the same amount of commodities as before using the money they have earned. It goes without saying that an entrepreneur is taking a big risk by reducing investment. Its competitors aren't dozing: they improve the production process, purchase new equipment, increase output, improve labor conditions and increase wages. And after a certain time, the entrepreneur may discover with surprise that labor productivity at his/her enterprise is lower than for competitors. At this moment, the entrepreneur begins to suffer loses and will be forced to apply titanic efforts to surviving and retaining its place on the market. Undoubtedly entrepreneurs and owners of the means of production spend a certain quantity of funds on personal consumption. Moreover, they sometimes have the opportunity to acquire luxury items. But they receive their remuneration after sale of produced products, and for this reasons it is characterized by extreme volatility and depends on the effectiveness of the production process an entrepreneur is implementing.

Change to total producer profit is distinctly cyclical in character. Competition and attempts to generate profit require producers to use the most progressive technologies and most perfected methods of management control that are available at a given moment in time. When the overwhelming majority of producers reach the limit of their productive potential, profits and economic growth approach zero. Prices for all resources become equal to their marginal product and enterprises' expenses become equal to their gains. The absence of profits does not allow for investment and growth ceases. From this moment forward the markets becomes perfect competition markets. Enterprises and the economy as a whole have achieved the limit of their effectiveness and producers are not in a position to produce more goods than they already are from the available resources. Supply curves become perfectly straight and vertical. In such cases, even an absolute monopoly cannot increase its gain and receive a profit. All of the numerous conditions usually included in economics textbooks are not necessary for the existence of perfect competition markets. The sole condition that is necessary and which suffices for the creation of such markets is the halt of economic growth. A perfect competition market is a market that is in a state of economic crisis. The absence of profit does not allow entrepreneurs to make investments and as such they strive to decrease their expenditures by making staff cuts. As follows from equation (1), the growth of unemployment gives rise to price reduction for goods and services and (or) to a fall in production. There arise problems with paying back loans that were received earlier. Enterprises have no available funds because they are generating no profit. In all eras, economies have periodically reached the limit of their productive potentials; crises have always existed. They were given more thorough attention 200 years ago because they began to take place more often and take on a global character. The successes of the free market economy and significant achievements in science and technology accelerated the average yearly rate of growth in leading economies tens or hundreds of times over, and for this reason many countries approached the limits of their productive potentials much more quickly. The usual crisis occurred once every ten to fifteen years. The more imperfect the market, the 
slower a certain region developed, the more potentials it contained. Free resources and capital trended in those directions, growth in those markets and regions sharply accelerated and economies enter periods of crisis practically simultaneously. The lone potential for enterprises in crisis conditions to generate profit is sharp increase to the productivity of utilized resources. This can be achieved only through the introduction of new technologies, new materials and new management techniques. Innovation allows the leaders to escape the vice-like grip of perfect competition, become temporary monopolies and receive their justly deserved profits. At this moment, competition takes on the characteristics of imperfect competition. The others chase after the leaders, not wanting to accept losses. When half of the resources begin to be used effectively, economic growth in the economy achieves its maximum value. This is followed by a steady recession and strengthening competition. The inverse relationship between the amount of inflation and the level of unemployment is clearly expressed during periods of declining economic growth. At the moment when practically all enterprises are working at maximum effectiveness and further expansion of production is impossible, markets become perfect competition markets and are plunged into the next crisis. The length of the cycle depends on the quantity of innovations available and their complexity. Total economic growth for the entire cycle depends on the effectiveness of the innovations that are implemented.

Why does interest exist? Why do we value current and future commodities differently? Why, when offering someone money in the form of a loan, do we demand that they return it with some sort of premium? The sole reason for the existence of interest is economic growth. Moreover, the equilibrium interest rate is equal to the amount of economic growth expressed as a percentage. Indeed, when, having offered somebody a commodity on loan, we discover that their production doubled during a certain period of time, we fairly demand that we be returned two units of the commodity. We value current commodities more than future ones because current commodities will increase down the road. A producer that has invested a loan $\mathrm{s} /$ he received in production and thereby doubled output of commodities receives $100 \%$ profit on the invested funds. It is precisely that amount of interest that $\mathrm{s} / \mathrm{he}$ is capable of returning. Our wages, expressed in the cost of the indicated commodity, also double. For this reason, a $100 \%$ interest rate seems completely fair to us.

It's obvious that interest is defined by the market, and this is why loans are accessible only to enterprises whose profits exceed average profit. Only the most effective enterprises are able to expand production, purchase additional resources and capital and assimilate unsuccessful competitors. But the picture changes when the powers that be attempt to artificially regulate the interest rate. This takes place particularly often in a period of diminishing economic growth. Specialists that are responsible for economic policy hope that reduction of interest rates will increase economic activity, increase investment and expand production. But, as a rule, if this leads to some sort of result, it won't be for very long. Growth slows for natural reasons: labor productivity approaches its maximum value for this level of development of productive forces. In this situation, a lower interest rate cannot change anything. It can only give a false signal to market participants. One fine day, enterprises, generating little profit, will unexpectedly discover that loans have become accessible for them and will happily make 
use of the opportunity presented them. But real profits inexorably fall for all producers during a period of declining economic growth. Even the most economically viable producers will very quickly have problems paying back capital, and this will transform into a true catastrophe for their less successful competitors. The crisis will very quickly spread to the banking sector, which the authorities will rush to save using taxpayer funds. The troubles that follow will be blamed on greedy bankers, bull-headed producers and irrational consumers. In truth, it is precisely attempts at regulation that increased unemployment and reduced production in relation to those values that they would have taken if the market had functioned without any sort of intervention.

\section{References}

Barro, R. J., \& Sala-i-Martin, X. (2004). Economic Growth. Second Edition. The MIT Press. Cambridge.

Barry, N. P. (1979). Hayek's Social and Economic Philosophy. London. Macmillan.

Bohm-Bawerk, E. (1959). Capital and Interest. South Holland. IL. Libertarian Press.

Debreu, G. (1959). The Theory of Value. New York: John Wiley and Sons.

Eichner, A. S. (1985). Towards a New Economics. New York: M. E. Sharpe.

Gordon, R. J. (1974). Milton Friedman's Monetary Framework. Chicago, University of Chicago Press.

Heather, K. (2004). The Economics of Industries and Firms. Translated from English./M.: Finances and statistics.

Hicks, J. (2003). Theory of Economic History. Translated from English. NP «Economics Questions Magazine», Moscow.

Keynes, J. M. (1936). The General Theory of Employment, Interest and Money. London: Macmillan.

Mas-Colell, A. (ed.). (1982). Non-cooperative Approaches to the Theory of Perfect Competition. New York: Academic Press.

Minsky, H. P. (1978). The financial instability hypothesis: a restatement. Thames Papers in Political Economy. Autumn.

Panorama of Economic thought in the end of the $20^{\text {th }}$ century. (2002). Edited. D. Greenway, M. Blini, I. Stewart, in two books. Translated from English by economic School edition, State University for Economic and Finances in St.-Petersburg.

Samuelson, P. A., \& Nordhaus W. D. (2004). Microeconomics. Eighteenth Edition. Irwin McGraw-Hill.

Sawyer M. (1985). Economics of Michal Kalecki. London: Macmillan.

Schumpeter, J. A. (2007). Theory of Economic development. Capitalism, socialism and 


\section{Macrothink}

Business and Economic Research

ISSN 2162-4860 2012, Vol. 2, No. 2

democracy. Translated from English. -M.: Eksmo.

Schumpeter, J. A. (2004). The History of economic analysis. In 3 books. Translated from English. Edition. School of Economics, State University for Economic and Finances in St.-Petersburg.

Stigler, G. (1957). Perfect competition, historically contemplated. Journal of Political Economy, 65, 1-17. http://dx.doi.org/10.1086/257878

The New Palgrave. (1987). The World of Economics. Edited by Eatwell J., Milgate M., Newman P.

\section{Copyright Disclaimer}

Copyright reserved by the author(s).

This article is an open-access article distributed under the terms and conditions of the Creative Commons Attribution license (http://creativecommons.org/licenses/by/3.0/). 